\title{
EFFECT OF VACCUUM LEVEL, PULSATION RATIO, CLAW SIZE AND USING DUOVAC UNIT ON PERFORMANCE OF MACHINE MILKING OF FRIESIAN COWS \\ Abedelatif, S.M. ${ }^{\star A}$. F. Mehrez ${ }^{\star *}$ and H. H.Tarabye* \\ * Agricultural Engineering Department, Faculty of Agriculture, Mansoura University. \\ ** Animal Production Research Institute, Agricultural Research Center, Ministry of Agriculture.
}

\begin{abstract}
The main objectives of this study were, to investigate the influence of different vacuum levels (VL), pulsation ratio (PR), claw size (CS) and connection of Duovac unit on characteristics of milking machine, in order to provide preliminary information for future trials on milk flow rate and milking time of Friesian cows. The present study was carried out at Sakha Animal Production Research Station, Kafr ElSheikh Governorate. Results revealed that machine milking yield (MMY) increased $(P<0.05)$ from $8.7 \mathrm{~kg}$ at $\mathrm{VL}$ of $48 \mathrm{kp}_{\mathrm{a}}$ to 9.0 and $9.05 \mathrm{~kg}$ at $\mathrm{VL}$ of 50 and $52 \mathrm{kp}_{\mathrm{a}}$, respectively. Total milk yield (TMY) increased $(P<0.05)$ as the $V L$ increased from 48 $(8.9 \mathrm{~kg})$ up to $52 \mathrm{Kpa}(9.8 \mathrm{~kg})$. Stimulation time $(\mathrm{ST})$ was shorter $(\mathrm{P}<0.05)$ at $50 \mathrm{Kpa}$ than at $52 \mathrm{Kp}_{\mathrm{a}}(10.4 \mathrm{vs} .10 .9 \mathrm{sec})$. Machine milking time (MMT) decreased $(P<0.05)$ from 4.4 to 3.9 min by increasing VL from 48 to $50 \mathrm{kp}_{\mathrm{a}}$ and to $3.5 \mathrm{~min}$ at $52 \mathrm{kp}_{\mathrm{a}}$. Stripping milk yield (SMT) only increased $(\mathrm{P}<0.05)$ from $0.6 \mathrm{~min}$ at $50 \mathrm{kp}_{\mathrm{a}}$ to $0.9 \mathrm{~min}$ at $52 \mathrm{kp}$. Total milking time (TMT) decreased $(\mathrm{P}<0.05)$ from $4.9 \mathrm{~min}$ at $48 \mathrm{kp}_{\mathrm{a}}$ to 4.6 and $4.4 \mathrm{~min}$ at 50 and $52 \mathrm{kp}_{\mathrm{a}}$, respectively. Milk flow rate (MFR) increased $(P<0.05)$ from 2.0 to $2.3 \mathrm{~kg} / \mathrm{min}$ at $50 \mathrm{kpa}$ and to $2.8 \mathrm{~kg} / \mathrm{min}$ at $52 \mathrm{kp}$. Stripping milk yield (SMY) relative to TMY was higher $(2.7 \%, \mathrm{P}<0.05)$ for $48 \mathrm{Kp}_{\mathrm{a}}$ than 50 and $52 \mathrm{Kp}_{\mathrm{a}}(2.3$ and $2.4 \%)$. Values of MMY decreased $(P<0.05)$ only by changing $P R$ from 65:35 up to 70:30 (8.7 vs. $9.2 \mathrm{~kg})$. SMY decreased $(\mathrm{P}<0.05)$ by $33 \%$ only with changing PR from $60: 40$ to $65: 35$. TMY decreased $(P<0.05)$ from 9.7 to $9.4 \mathrm{~kg}$ by changing $P R$ from 60:40 to 65:35. However, changing $P R$ from 65:35 to 70:30 reduced $(P<0.05)$ TMY from 9.4 to $8.9 \mathrm{~kg}$. ST decreased $(P<0.05)$ from 11.3 to $10.5 \mathrm{sec}$ only by changing pulsation ratio from $60: 40$ to $65: 35$. TMT was longer (1.9 vs. $4.6 \mathrm{~min}, \mathrm{P}<0.05$ ) by changing PR from $60: 40$ to $65: 35$ and from $65: 35$ to $70: 30$ (4.6 vs. $4.5 \mathrm{~min}, \mathrm{P}<0.05$ ). SMT decrease $(P<0.05)$ from 0.70 to $0.68 \mathrm{sec}$ only by changing $P R$ from $60: 40$ up to 70:30. MMT decreased $(P<0.05)$ by changing $P R$ from $60: 40$ to $65: 35$ or to $70: 30$, being 4.2, 3.9 and 3.8 min, respectively. MFR increased $(P<0.05)$ from 2.3 to 2.4 $\mathrm{kg} / \mathrm{min}$ only by changing PR from $60: 40$ to $65: 35$. Percentage of SMY relative to TMY decreased $(P<0.05)$ from $2.7 \%$ at $60: 40$ to $2.4 \%$ to $2.4 \%$ at $65: 35$ and changing $P R$ to 70:30 decreased $(P<0.05)$ percentage of SMY to TMY to $2.3 \%$. SMY, ST, TMT, SMT, MMT and SMY relative to TMY were higher $(P<0.05)$ with claw size of 150 than 350 $\mathrm{cm}^{3}$. However, TMY and MMY were higher $(\mathrm{P}<0.05)$ with claw size of 350 than 150 $\mathrm{cm}^{3}$. Increasing claw size from 150 to 350 increased $(P<0.05)$ MFR from 2.2 to 23.5 $\mathrm{kg} / \mathrm{min}$, increased $(\mathrm{P}<0.05)$ MMY from 8.9 to $9.3 \mathrm{~kg}$ and decreased TMT, whereas SMY was the same in both cases of claw size. Using Duovac unit resulted in increase $(\mathrm{P}<0.05)$ in MMY from 9.0 to $9.2 \mathrm{~kg}$ and in TMY from 9.3 to $9.4 \mathrm{~kg}$ and decrease $(\mathrm{P}<0.05)$ in $\mathrm{ST}$ and MMT leading to reduction $(\mathrm{P}<0.05)$ in TMT from 4.9 to $4.5 \mathrm{~min}$ and increase $(\mathrm{P}<0.05)$ in MFR from 2.3 to $2.5 \mathrm{~kg} / \mathrm{min}$ as compared to without using. Values of SMY decreased $(P<0.05)$ from 0.3 to $0.2 \mathrm{~kg}$ and TMY increased $(P<0.05)$ and SMY relative to TMY decreased $(\mathrm{P}<0.05)$ from 2.8 to $2.1 \%$.

Keywords: Milking machine, vacuum, pulsation, claw, Duovac unit, milk flow rate.
\end{abstract}




\section{INTRODUCTION}

The goal of the milking program is to harvest the maximum amount of high quality milk with minimum udder irritation. Milking is the most important single job on a dairy farm. All milking machines have the same basic elements such as vacuum system, pulsation equipment, milking units (cluster) and milk receptacle. The purpose of the vacuum pump is to exhaust air continuously from the milking machine system. Pulsation operation is the opening and closing of the liners in the teat cups. The pulsator alternately connects the pulsation chambers to the vacuum system of machine and to the atmosphere (Akam, 1979). The main purpose of pulsation is to maintain blood circulation through the teat (Neave, 1959). A complete breakdown in pulsation could result in serious mastitis problems and more infections were happened with wide variation in ratio and rate (Kingwill et al., 1979).

Several investigations had been carried out on the engineering factors affecting machine milking. They have been established that changes in the curve of the milk flow in the course of a pulsation depend on the reaction of the teat sphincter to the influence of the teat liner vacuum (Theil et al., 1977). Thiel and Mein (1979) reported that there are two potential uses of milk flow rate in the automatic management of dairy animals. First, as an aid to milking machine control and second as an aid to detection of health changes. The rate of milk flow changes as the characteristics of pulsation and vacuum level are changed.

Vacuum level of $51.11-57.89 \mathrm{kp}_{\mathrm{a}}$ is an appropriate level for Egyptian buffaloes (Hassan, 1970). The effect of different vacuum levels on total milking time, machine milk yield and milk flow rate were investigated by several authors (Aliev, 1970 and Hassan, 1970). Akam (1980) found that higher levels of vacuum would give faster milking but milking would be less complete, capital costs higher and it is popularly believed that mastitis would increased. Also, the interaction between vacuum level and pulsation ratio was studied by Mahle et al. (1982) on milk flow rate and udder health. The faster pulsation ratios would give faster milking but with higher operating costs (Akam, 1980; Hamed, 1982; Rosen et al., 1983; Hamed and Nigm, 1986 and Thomas et al., 1991).

On the other hand, increasing the claw volume had many effects than would be expected from placement of vacuum reservoir near the teats. Vacuum was stabilized by this reservoir but air flow through the long milk tube in response to changes in milk line vacuum was greater than it would be with smaller claw volume. The claws are different in diameter and the larger claw had an advantage on yield and flow milk rate (Thompson and Pearson, 1983). Duovac is a system represents the intermediate stage between manual and automatic cluster removal in milking machine. It make gentle massaging to the teats in a low vacuum level during stimulation and postmilking phases and reduces the risk of over milking during milking phase (Reinemann and Mein, 1994). This study aimed to determine the optimal vacuum level, pulsation ratio and claw size for maximum milk yield with the 
shortest machine milking time (maximum milk flow rate) of Friesian cows. Also, the effect of using Duovac unit in milking machine was investigated.

\section{MATERIALS AND METHODS}

The present study was carried out at Sakha Animal Production Research Station, Kafr El-Sheikh Governorate, belonging to Animal Production Research Institute, Agricultural Research Center, Ministry of Agricultural in cooperation with Department of Agricultural Engineering, Faculty of Agriculture, Mansoura University. The experimental work lasted 288 days during an experimental period from May 2002 to April 2003. The data for this study contained 6912 morning (a.m.) milkings for 24 Friesian cows.

Animals:

Animals used in this work were chosen from the Friesian herd raised at the station. A total number of 24 lactating Friesian cows averaged $495.6 \pm 10.0$ $\mathrm{kg}$ LBW, and ranged between 3- 8 years of age and between the $1^{\text {st }}$ and 4 th parity was used in this study. The experimental animals were used after 3-4 days of colostrum suckling up to 144 days as early lactation period, thereafter the experiment was repeated for 144 days as lat lactation period to avoid the variation in lactation period between animals.

During the experimental period, animals were fed concentrate feed mixture (CFM) plus hay during summer and CFM plus berseem during winter according to NRC (1984). All cows were housed in similar dry lot housing and cows were fed identical rations and milked twice a day at 6 a.m. and 4 p.m. in nearly identical double 8 herringbone milking parlors, each parlor utilized two milkers and cows were delivered to each parlor by one stockman. Only data of morning milking was recorded.

\section{Characteristics of milking machine:}

The Gascoigne pipeline milking machine was used throughout the study. Technical information of milking machine equipment [vacuum pump model Vac 4A (cillubricated), Serial Number 482833812] are presented in table (1). It was driven by electric motor Mez. Mohelice serial Number 2386478IP44B3.

The effect with one of two types of milking claw were investigated, the first was common type with a large claw volume $\left(350 \mathrm{~cm}^{3}\right)$, and used alternate pulsation. The second was more traditional type with $150 \mathrm{Cm}^{3}$.

Douvac system (Alfa-Laval Duovac 300) was attached during the interval studying the effect of Duovac with different levels of vacuum. Pulsation ratio and claw size.

Milk meter (Alfa-Laval Agric., Mark 5, maximum capacity $30 \mathrm{~kg}$ ) was used to measure the total milk yield and the milk flow rate. Milk meter used in pipeline system was fixed in special stand with Duovac to measure the milk yield $(\mathrm{kg})$ from each cows.

\section{Experimental procedures:}

A total of 36 trails ( 3 vacuum levels $\times 3$ pulsation ratio $\times 2$ claw size with or without Duovac), each trail lasted for 8 days ( 4 days during the early lactation stage and 4 days during the late lactation stage) was conducted. 
Abedelatif, S.M. et al.

Table (1): Technical information of Gascoigne melotte vacuum pump.

\begin{tabular}{|c|c|c|c|c|c|c|c|c|c|}
\hline \multicolumn{2}{|c|}{$\begin{array}{c}\text { Tow- } \\
\text { exhoust }\end{array}$} & \multirow{2}{*}{$\begin{array}{l}\text { Pump capacity } \\
(1 / \mathrm{min} \text {. at } 50 \mathrm{kpa})\end{array}$} & \multirow{2}{*}{$\begin{array}{l}\text { Pump } \\
\text { speed } \\
\text { (rpm) }\end{array}$} & \multirow{2}{*}{$\begin{array}{c}\text { Pump } \\
\text { power } \\
\mathrm{Kw}\end{array}$} & \multirow{2}{*}{$\begin{array}{c}\text { Pump } \\
\text { power } \\
\text { h.p. }\end{array}$} & \multirow{2}{*}{$\begin{array}{l}\text { Lubrication } \\
\text { oil, } \mathbf{g} / \mathbf{h}\end{array}$} & $\begin{array}{l}\begin{array}{l}\text { Electric } \\
\text { motor }\end{array} \\
\end{array}$ & \multirow{2}{*}{$\begin{array}{c}\text { Pump } \\
\text { type }\end{array}$} & \multirow{2}{*}{$\begin{array}{c}\text { Electric } \\
\text { motor } \\
\text { speed } \\
(\mathrm{rpm})\end{array}$} \\
\hline Port & Sizes & & & & & & & & \\
\hline 50 & 60 & 1300 & 900 & 3 & 2.23 & 10 & 4 & \begin{tabular}{l|l|} 
Vac4A \\
\end{tabular} & 1440 \\
\hline
\end{tabular}

Milking intervals for each animal were maintained at 12 hours throughout the first 144 days and at 10 hours throughout the last 144 days of the experiment. Milking machine was adjusted for different vacuum levels (48, 50 and $52 \mathrm{Kpa}$, pulsation ratio (60:40, 65:35 and 70:30) claw sizes (150 and $350 \mathrm{~cm}^{3}$ ) with or without using Douvac. While, pulsation rate was set at 60 cycles per min.

When all teat cups were attached to the udder a stop watch was started, milk yield was recorded at interval of 30 seconds throughout milking and when the milk flow fell "ceased" below $0.100 \mathrm{~kg}$ between two consecutive readings the machine stripping was started and continued until the cessation of milk flow then the cluster was removed. The following measurements were taken for each milking: stimulation time, machine milking time, stripping time machine milking yield, total milking yield

1- Stimulation time (ST):Time elapsed from last teat cup was attached until the start milk let down

2- Machine milking time (MMT): The duration between the attachment of the milking until to the cessation of milk flow.

3- Stripping time(SRT): The time was measured when milk flow rate less than $0.100 \mathrm{~kg} / \mathrm{min}$, the udder was massaged and tension below until milk flow rate stop.

4- Total milking time $(T M T)=S T T+M M T+S R T$

5- Machine milk yield (MMY)

6- Stripping milk yield (SMY)

7- Total milk yield $(T M Y)=M M Y+S M Y$

8- Milking flow rate (MFR): was measured during machine milking and was calculated as machine milk yield $(\mathrm{kg}) /$ minute milking time.

\section{Experimental design:}

The experiment was designed such that each cow would receive every vacuum level for 48 consecutive days during which the pulsation ratio (60:40, 65:35 and 70:30) was adjusted every 16 days, claw size (150 and 350 $\mathrm{cm}^{3}$ ) was changed every 8 days and Douvac was used (+) or not (-) every days). This period represented for the three vacuum levels the first 144 consecutive days as $1^{\text {st }}$ phase of lactation, thereafter it was repeated for other 144 consecutive days to avoid individual variations between cows. Throughout the experimental period of 288 days a total of 6912 morning milkings were observed ( 3 vacuum levels $x 3$ pulsation ratios $x 2$ claw size $x$ Douvac $\times 24$ cows $\times 4$ days $\times 2$ phases) as shown in table (2). During all milkings, the pulsation rate was kept constant at $60 \mathrm{ppm}$ according to (Spencer et al., 1993).

There was a preliminary period of two days before applying a different vacuum level for the cows to adjust to the new adjustment level. 
Table (2): Experimental design for different vacuum pressures $\left(k_{\mathrm{a}}\right)$, pulsation rations and claw sizes $\left(\mathrm{cm}^{3}\right)$ with and without duovac for each lactation phase.

\begin{tabular}{|c|c|c|c|c|c|c|}
\hline $\begin{array}{l}\text { Vacuum } \\
\text { level }\left(k p_{a}\right)\end{array}$ & $\begin{array}{l}\text { Pulsation } \\
\text { ratio }\end{array}$ & $\begin{array}{l}\text { Claw } \\
\text { size } \\
\left(\mathrm{cm}^{3}\right)\end{array}$ & Duovac & $\begin{array}{l}\text { Number of } \\
\text { animals } \\
\text { (n) }\end{array}$ & $\begin{array}{c}\text { Exp. } \\
\text { Interval } \\
\text { (day) }\end{array}$ & $\begin{array}{c}\text { No. of } \\
\text { observ- } \\
\text { ation }\end{array}$ \\
\hline \multirow{12}{*}{48} & \multirow{4}{*}{$60: 40$} & \multirow{2}{*}{150} & With & 24 & 4 & 96 \\
\hline & & & Without & 24 & 4 & 96 \\
\hline & & \multirow{2}{*}{350} & With & 24 & 4 & 96 \\
\hline & & & Without & 24 & 4 & 96 \\
\hline & \multirow{4}{*}{$65: 35$} & \multirow{2}{*}{150} & With & 24 & 4 & 96 \\
\hline & & & Without & 24 & 4 & 96 \\
\hline & & \multirow{2}{*}{350} & With & 24 & 4 & 96 \\
\hline & & & Without & 24 & 4 & 96 \\
\hline & \multirow{4}{*}{ 70:30 } & \multirow{2}{*}{150} & With & 24 & 4 & 96 \\
\hline & & & Without & 24 & 4 & 96 \\
\hline & & \multirow{2}{*}{350} & With & 24 & 4 & 96 \\
\hline & & & Without & 24 & 4 & 96 \\
\hline \multicolumn{4}{|c|}{ Total for vacuum level of $48 \mathrm{Kpa}$} & 24 & 48 & 1152 \\
\hline \multicolumn{4}{|c|}{ Total for vacuum level of $50 \mathrm{Kpa}$} & 24 & 48 & 1152 \\
\hline \multicolumn{4}{|c|}{ Total for vacuum level of $52 \mathrm{Kpa}$} & 24 & 48 & 1152 \\
\hline \multicolumn{4}{|c|}{ Total for three vacuum levels } & 24 & 144 & 6912 \\
\hline
\end{tabular}

\section{Statistical analysis:}

Data were statistically analyzed using a model that included effect of vacuum level, pulsation ratio, claw size and using Duovac and their interaction according to Snedecor and Cochran (1982). The significant differences among treatment groups were tested using Duncan's Multiple Range Test Duncan (1955).

\section{RESULTS AND DISCUSSION}

\section{Effect of vacuum level on machine milking characteristics:}

In milking machines, the vacuum is applied to the teat wall create pressure difference between the intra-mammary and the external atmospheric pressure, so that milk pressure can overcome the resistance of the teat sphincter muscle and flow out of the udder.

Data presented in table (3) revealed that machine milk yield, stripping milk yield and subsequently total milk yield significantly increased by increasing vacuum level from 48 to $52 \mathrm{kp}_{\mathrm{a}}$. The marked increase in total milk yield was mainly attributed to increasing not only machine milk yield but also in stripping milk yield. In contrast to the present results concerning milk yield, Ivanov and Grozev (1990) reported that increasing vacuum level had no clear effect on milk yield of mechanically milked cows.

Stimulation time was insignificantly decreased $(10.4 \mathrm{sec})$ at $50 \mathrm{Kpa}$ and increased $(\mathrm{P}<0.05)$ at $\mathrm{Kp}_{\mathrm{a}} 52$ than that at $48 \mathrm{Kpa}(10.6 \mathrm{vs}, 10.9 \mathrm{sec})$. However, the difference was significant $(\mathrm{P}<0.05)$ by increasing vacuum level from 50 to $52 \mathrm{Kpa}_{\text {(Table 3). }}$ 
Abedelatif, S.M. et al.

Table (3): Effect of vacuum level (VL) on milking characteristics of Friesian cows during morning milking.

\begin{tabular}{|c|c|c|c|}
\hline \multirow{2}{*}{ Item } & \multicolumn{3}{|c|}{ Vacuum level $(\mathrm{Kpa})$} \\
\hline & 48 & 50 & 52 \\
\hline \multicolumn{4}{|c|}{ Milk yield $(\mathrm{kq})$ : } \\
\hline Machine milk yield & $8.7 \pm 0.08^{c}$ & $9.0 \pm 0.09^{b}$ & $9.5 \pm 0.07^{a}$ \\
\hline Stripping milk yield & $0.2 \pm 0.008^{b}$ & $0.2 \pm 0.006^{b}$ & $0.3 \pm 0.008^{a}$ \\
\hline Total milk yield & $8.9 \pm 0.08^{c}$ & $9.2 \pm 0.09^{b}$ & $9.8 \pm 0.07^{a}$ \\
\hline \multicolumn{4}{|c|}{ Milking time (min): } \\
\hline Machine milking time & $4.4 \pm 0.05^{\mathrm{a}}$ & $3.9 \pm 0.04^{b}$ & $3.5 \pm 0.04^{c}$ \\
\hline Stripping milk time & $0.5 \pm 0.01^{c}$ & $0.6 \pm 0.02^{b}$ & $0.9 \pm 0.02^{\mathrm{a}}$ \\
\hline Total milking time & $4.9 \pm 0.05^{a}$ & $4.6 \pm 0.05^{b}$ & $4.4 \pm 0.04^{c}$ \\
\hline \multicolumn{4}{|c|}{ Machine milking characteristics: } \\
\hline Milk flow rate (kg/min) & $2.0 \pm 0.30^{c}$ & $2.3 \pm 0.30^{\mathrm{b}}$ & $2.8 \pm 0.40^{\mathrm{a}}$ \\
\hline Stripping /total milk yield (\%) & $2.7 \pm 0.08^{a}$ & $2.3 \pm 0.07^{b}$ & $2.4 \pm 0.08^{b}$ \\
\hline
\end{tabular}

Machine milking time gradually decreased $(P<0.05)$ from 4.4 to 3.9 min by increasing vacuum level from 48 to $50 \mathrm{kp}_{\mathrm{a}}$ and to $3.5 \mathrm{~min}$ at $52 \mathrm{kpa}$. The observed decrease in machine milk time was in an opposite trend of increased stimulation time by increasing vacuum level. This may indicate reversible relationship between stimulation time and machine milking time as affected by vacuum level. In parallel pattern with machine milking time, total milking time gradually decreased $(\mathrm{P}<0.05)$ from 4.9 to $4.6 \mathrm{~min}$ by increasing vacuum level from 48 to $50 \mathrm{kpa}$ and to $4.4 \mathrm{~min}$ at $52 \mathrm{kpa}$ (Table 3). Such trend indicated that total milking time was affected mainly by machine milking time rather than stripping milk yield and did not related to stimulation time. Also, it was found that increasing machine milking time led to marked reduction in stripping milk time. The obtained results regard to milking time agreed those found by Aliev (1970), who studied the effect of two vacuum levels ( 46.5 and $56.5 \mathrm{kpa}$ ) on total milking time of in buffaloes, founding that increasing the vacuum level caused decrease in the total milking time. In addition, Hassan (1970) investigated the effect of increasing the vacuum level from 50 to 55.2 and to $63.1 \mathrm{kpa}$ on total milking time of buffaloes. He observed a decrease in total milking time in morning and evening milkings. In this respect, Akam (1980) Mentioned that the relatively small reduction in milking time that can be achieved by increasing vacuum level is not essential in achieving large improvement in the labour economy of milking.

Milking flow rate gradually increased $(P<0.05)$ by increasing vacuum level. The noticed increase in milking flow rate by increasing vacuum level was in relation to increased milk yield and decreased time of machine milking (Table 3). The present findings are in agreement with those reported on buffaloes by Hassan (1970), who found that average milk flow rate increased by increasing vacuum level from 50 to 55.2 and to $63.1 \mathrm{kp}$, but machine milk yield decreased slightly. Similar findings were reported by Schmidt et al. (1963) on cows.. 
Stripping milk relative to total milk yield increased $(P<0.05)$ by increasing vacuum level from 48 to $50 \mathrm{Kp}$, but did not differ significantly between 50 and $52 \mathrm{kpa}$ vacuum levels (Table 3 ). Such trend may reflect higher milking efficiency at 50 or 52 than at $48 \mathrm{Kpa}$ vacuum levels. The obtained results agreed many investigators who reported that most of the milking machines are operated for milking cows at vacuum level ranging from 45 to $50 \mathrm{kpa}_{\text {a }}$ (Schmidt et al., 1963). However, Hassan (1970) reported that vacuum level of $51.11-57.89 \mathrm{kp}_{\mathrm{a}}$ is the appropriate vacuum level for Egyptian buffaloes.

\section{Effect of pulsation ratio on machine milking characteristics:}

The pulsation rate was kept at 60 cycles/min during the whole experimental period, however, pulsation ratio was changed from 60:40 to 65:35 and to 70:30. Table (4) shows the obtained values of all milking characteristics as affected by different pulsation ratios.

Machine milk yield, stripping milk yield and consequently total milk yield showed significantly $(P<0.05)$ a gradual reduction by changing pulsation ratio from 60:40 to $65: 35$ or to $70: 30$. The optimum pulsation ratio for the highest milk yields was obtain with 60:40 pulsation ratio, regardless the other factors (e.g. vacuum level, claw size and using Duovac).

These findings are in consistent with that reported by Rosen et al, (1983), who reported that increasing pulsation ratio caused pronounced changes in the stripping milk yield.

The marked reduction in total milk yield with changing pulsation ratio from 65:35 to 70:30 was mainly attributed to the significant decrease in machine milk yield not in stripping milk yield as affected by changing pulsation ratio (Table 4). Decreasing machine milk yield with altered pulsation ratio from 60:40 to $70: 30$ may be due to that teat cups might crawl up the udder teats, and close the orifice between the teat cisterns and the gland cisterns causing the retention of more amounts of milk inside the udder cows.

Table (4): Effect of pulsation ratio (PR) on milking characteristics of Friesian cows during morning milking.

\begin{tabular}{|c|c|c|c|}
\hline \multirow{2}{*}{ Item } & \multicolumn{3}{|c|}{ Pulsation ratio } \\
\hline & $60: 40$ & $65: 35$ & $70: 30$ \\
\hline \multicolumn{4}{|l|}{ Milk yield $(\mathbf{k g})$ : } \\
\hline Machine milk yield & $9.4 \pm 0.8^{a}$ & $9.2 \pm 0.8^{b}$ & $8.7 \pm 0.9^{c}$ \\
\hline Stripping milk yield & $0.31 \pm 0.008^{a}$ & $0.24 \pm 0.007^{b}$ & $0.20 \pm 0.006^{c}$ \\
\hline Total milk yield & $9.7 \pm 0.8^{a}$ & $9.4 \pm 0.8^{\mathrm{b}}$ & $8.9 \pm 0.9^{c}$ \\
\hline Stimulation time (sec) & $11.3 \pm 2.7^{a}$ & $10.5 \pm 1.8^{b}$ & $10.2 \pm 2.0^{c}$ \\
\hline \multicolumn{4}{|l|}{ Milking time (min): } \\
\hline Machine milking time & $4.2 \pm 0.05^{a}$ & $3.9 \pm 0.05^{b}$ & $3.8 \pm 0.06^{b}$ \\
\hline Stripping milk time & $0.70 \pm 0.02^{\mathrm{a}}$ & $0.69 \pm 0.02^{a b}$ & $0.68 \pm 0.03^{b}$ \\
\hline $\begin{array}{l}\text { Total milking time } \\
\text { Machine milking characteristics: }\end{array}$ & $4.9 \pm 0.04^{\mathrm{a}}$ & $4.6 \pm 0.05^{\mathrm{b}}$ & $4.5 \pm 0.05^{\mathrm{b}}$ \\
\hline Milk flow rate $(\mathrm{kg} / \mathrm{min})$ & $2.3 \pm 0.04^{b}$ & $2.4 \pm 0.04^{a}$ & $2.4 \pm 0.05^{a}$ \\
\hline Stripping /total milk yield (\%) & $2.7 \pm 0.09^{a}$ & $2.4 \pm 0.08^{b}$ & $2.3 \pm 0.07^{\mathrm{b}}$ \\
\hline
\end{tabular}

a, $b$ and $c$ : Means denoted within the same column with different superscripts are significantly different at $\mathrm{P}<0.05$. 
Abedelatif, S.M. et al.

Stimulation time significantly $(P<0.05)$ decreased from 11.3 to 10.5 sec by changing pulsation ratio from $60: 40$ to $65: 35$. However, changing pulsation ratio from $65: 35$ to $70: 30$ significantly decreased stimulation time from 10.5 to $10.2 \mathrm{sec}$. It is worthy noting that changing pulsation ratio from 60:40 to 65:35 resulted in more pronounced reduction in stimulation time than that occurred when pulsation ration changed from 65:35 to 70:30. The shortest stimulation time was associated with pulsation ratio of 70:30 (Table $4)$.

As the times of machine milking and stripping milk decrease, total milking time significantly $(P<0.05)$ decreased from 4.9 to 4.6 min by changing pulsation ratio from 60:40 to 65:35, while all milking times were not affected significantly by changing pulsation ratio from $65: 35$ to $70: 30$. The observed reduction time of total milking time when pulsation ratio was changed from 60:40 to $65: 35$ was in more relation to marked reduction in machine milking time than in stripping milk time (Table 4).

The detected higher milk yields with pronounced reduction in milking times by changing pulsation ratio from 60:40 to 65:35 was reflected in significant $(P<0.05)$ increase in rate of milk flow from 2.3 to $2.4 \mathrm{~kg} / \mathrm{min}$. However, changing pulsation ratio from $65: 35$ to $70: 30$ did not effect significantly on milk flow. The nearly similarity in milk flow rate at pulsation ratios of 65:35 and 70:30 was mainly attributed to the higher reduction in total milk yield and the slight decrease in total milking time by chancing pulsation ratio from 65:35 to 70:30 (Table 4).

Percentage of stripping milk yield to total milk yield significantly $(P<0.05)$ decreased from $2.7 \%$ at $60: 40$ to $2.4 \%$ at $65: 35$ ratio and insignificantly decreased to $2.3 \%$ at $70: 30$ ratio. Such trend was mainly attributed to a marked decrease in total milk yield and slight decrease in stripping milk yield (Table 4).

Several investigations had been carried out on different pulsation ratios. They have been established that changes in the curve of the milk flow in the course of a pulsation depend on the reaction of the teat sphincter to the influence of the teat liner vacuum (Theil et al., 1977). The main purpose of pulsation is to maintain blood circulation through the teat (Neave, 1959).

A complete breakdown in pulsation could result in serious mastitis problems and more infections were happened with wide variation in ratio and rate of pulsation (Kingwill et al., 1979). A faster pulsation rates and ratios would give faster milking but with higher operating costs. The relatively small reduction in milking time that can be achieved in this way are not essential in achieving large improvement in the labour economy of milking (Akam, 1980).

Most of the available studies are in accordance with the present results indicating that changing pulsation ratio had significant effect on milk yield and milking time. In this respect, Rosen et al. (1983) found that increasing static ratio from 40:60 to 70:30 increased peak and average milking rates as well as milking stripping yield and, decreased time to reach milk yield peak and machine milking time. Also, Thomas et al. (1991) found that average machine milking times were $8.44,8.00$ and 7.47 min per milking for 50:50, 60:40 and 70:30 pulsation ratios, respectively. The pulsation ratio of $70: 30$ yielded $3.5 \%$ milk yield per milking more than ratio of 50:50 (13.0 vs. $13.8 \mathrm{~kg})$. Spencer et 
Such trend led to significantly $(\mathrm{P}<0.05)$ increased milk flow rate from 2.3 to $2.5 \mathrm{~kg} / \mathrm{min}$ and decreased stripping milk yield relative to total milk yield from 2.8 to $2.1 \%$ by using Duovac unit (Table 5 ).

Generally, using Duovac in milking machine had beneficial effects on increasing total milk yield and decreasing total milking time of Friesian cows. Duovac is a system represents the intermediate stage between manual and automatic cluster removal in milking machine. Duovac is a system represents the intermediate stage between manual and automatic cluster removal in milking machine (Reinemann and Mein, 1994). Unfortunately, there are no information in the literature on the effect of using Duovac unit in milking machine on characteristics of machine milking of dairy cows.

\section{Effect of interaction among different factors studied:}

Only the effect of interaction between vacuum level and pulsation ratio as well as between vacuum level and using Duovac was significant on milk flow rate, however, the effect of interaction among the other factors was not significant.

Table (6): The best levels for the highest milk flow rate (MFR\%) as affected by the interaction effect between factors studied.

\begin{tabular}{|c|c|c|c|c|c|c|}
\hline \multicolumn{5}{|c|}{ Interaction effect } & \multirow{2}{*}{\begin{tabular}{|c} 
Milk flow rate \\
$(\%)$
\end{tabular}} & \multirow{2}{*}{$\begin{array}{c}\text { Signifi- } \\
\text { canc }\end{array}$} \\
\hline Factors & VL $\left(k p_{a}\right)$ & PR & $\mathrm{CS}\left(\mathrm{cm}^{3}\right)$ & Duovac & & \\
\hline $\mathrm{VL} \times \mathrm{PR}$ & 52 & $70: 30$ & - & - & 2.9 & *** \\
\hline VL $\times$ CS & 52 & - & 350 & - & 2.9 & NS \\
\hline VL $x$ DU & 52 & - & - & with & 2.9 & $\star * *$ \\
\hline $\mathrm{PR} \times \mathrm{CS}$ & - & $70: 30$ & 350 & - & 2.6 & NS \\
\hline $\mathrm{PR} \times \mathrm{DU}$ & - & $70: 30$ & - & with & 2.5 & NS \\
\hline $\mathrm{CS} \times \mathrm{DU}$ & - & - & 350 & with & 2.6 & NS \\
\hline $\mathrm{VL} \times \mathrm{PR} \times \mathrm{CS}$ & 52 & $70: 30$ & 350 & - & 3.1 & NS \\
\hline $\mathrm{VL} \times \mathrm{PR} \times \mathrm{DU}$ & 52 & $70: 30$ & - & with & 3.0 & NS \\
\hline $\mathrm{VL} \times \mathrm{CS} \times \mathrm{DU}$ & 52 & - & 350 & with & 3.0 & NS \\
\hline $\mathrm{PR} \times \mathrm{CS} \times \mathrm{DU}$ & - & $70: 30$ & 350 & with & 2.7 & NS \\
\hline $\mathrm{VL} \times \mathrm{PR} \times \mathrm{CS} \times \mathrm{DU}$ & 52 & $70: 30$ & 350 & with & 3.1 & NS \\
\hline VL: Vacuum level & PR: Pu & ation r & & CS: Clan & ize & U: Duove \\
\hline
\end{tabular}

The highest milk flow rates were obtained with the highest vacuum level $\left(52 \mathrm{Kpa}_{\mathrm{a}}\right)$, the highest ratio of pulsation (70:30), the largest area of claw $\left(350 \mathrm{~cm}^{3}\right)$, and using Duovac unit (Table 6).

All milking machines have the same basic elements such as vacuum system, pulsation equipment, milking units (cluster) and milk receptacle. The purpose of the vacuum pump is to exhaust air continuously from the milking machine system. Pulsation operation is the opening and closing of the liners in the teat cups. The pulsator alternately connects the pulsation chambers to the vacuum system of machine and to the atmosphere (Akam, 1979). The rate of milk flow changes as the characteristics of pulsation and vacuum level are changed. In this respect, Thiel and Mein (1979) reported that there are two potential uses of milk flow rate in the automatic management of dairy animals. First, as an aid to milking machine control and second as an aid to detection of health changes. 


\section{EFERENCES}

Akam, D.k. (1979). Description And Performance Of Components In Machine Milking (Eds, C.C.Theil and F. H.Dodd), Reading National Institute for Research in Dairy (Nird-Hri technical PulletinNo.7). pp 37-101.

Akam, D.k. (1980). Technical development of milking machine. In: Mechanization And Automation Of Cattle Production. An Occasional publication of the British Society of Animal Production (BSAP. Reading 1980).

Alive, M.G. (1970). Physiology of machine milking in buffaloes. Dairy. Sci. Abstr. 32: (6):329-333.

Duncan, D.B. (1955). Multiple range and multiple F-test. Biometrics, 11:10.

Hamed, M.K. (1982). Techno-economic studies on milk production in cattle and buffaloes. Ph.D. Thesis, Fac. of Agric., Cairo Univ., Giza.

Hamed, M.K. and A.A. Nigm (1986). Effect of some physiological and mechanical factors on machine milking traits of Egyptian buffaloes. The $7^{\text {th }}$ Conference Of Animal Production, Cairo 16-18 September, 1986.

Hassan, G. A. (1970). Milking machine experiments with buffaloes. M.Sc. Thesis, Fac. of Agric. Alex. Univ.

Ivanove, I.P. and G.I. Grozev (1990). Effect of milking machine operating at different vacuum levels on milking of cows. J. Dairy Abstracts 52: 2252.

Kingwill, R.G.; F.H. Dodd and F.K. Neava (1979). Machine milking and mastitis. In: Machine Milking (Eds. C. C. Theil and F.H.Dodd) Reading: National Institute for Research in Dairy (NIRD-HRI) Technical Bulletin No (1). Pp. 231-262.

Mahle, D.E.; D.M. Gallon and R.W. Adkinson (1982). Effect of vacuum and pulsation ratio on udder health. J. Dairy Sci., 65: 1252 - 1257.

Neave, F.K. (1959). Milking machines and mastitis. In: Machine Milking. pp 104 - 160, London, HM Stationery Office MAFF Bulletin No. 177.

NRC (1984). Nutrient Requirement of Dairy Cattle (6 $\left.6^{\text {th }} \mathrm{Ed}\right)$. National Academy Press, Washington, D. C.

Reinemann, D.J. and G.A. Mein (1994). Transition from stratified to slug flow in milking. Transaction of the ASAE, 37 (2): 655-660.

Rosen, M.B.; E.V. Caruolo; R.D. Mochrie and D.A. Dickey (1983). Relationship of pulsation rate, pulsation ratio and vacuum decrease time to milking performance. J. Dairy Sci, 66: 2580.

Schmidt, G.H.; R.S. Guthrie; R. W. Guest; E.B. Hundtoft; A. Kumar, and C.R Henderson. (1963). Effect of changes in milking machine design on milking rate, machine stripping, and mastitis. Cornell Univ. Agric. Exp. Station. Bull. 983.

Snedecor, G.W. and W.G. Cochran (1982). Statistical Methods. 7th Ed. lowa Univ. Press, Ames. lowa, USA.

Spencer, S.B.; J.B. Cooper and G.W. Rogers (1993). Effect of change of pulsation rate and ratio up on new (IMI) and some milking characteristics. J. Dairy Sci., Annual meeting, 1993.

Thiel, C.C.; P.A. Clough and D.N. Akam (1977). Biological basis of designing and testing of milking machine. In: Physiology Of Milk Secretion In Machine Milking. (Ed. IG. Velitok) pp. 86-94 .Translated from Russian, American publishing Co. PVT. Ltd. 66 Japath, New Delhi.

Thiel, C.C. and G.A. Mein (1979). Action of the cluster during milking. In: Machine Milking, pp 117-125 (Eds. C.C. Theil and F.U. Dodd, Reading: National Institute for Research in Dairying, Reading England, (NIRDHRI Technical Bulletin No. 1). 


\section{Abedelatif, S.M. et al.}

Thomas, C.V.; D.K. Force. and, D.H. Bremel (1991). Effects of pulsation ratio, pulsation rate and teat cup liner design on milking rate and milk production. J. Dairy Sci., 74: 1243.

Thompson, P.D. and R.E. Pearson (1983). Milk droplet impacts during induced vacuum fluctuations: Influence of claw and other characteristics. J. of Dairy Sci., 66: 562-572.

تـأثير مسـتوى ضـغط التفريـغ، نسبة التبض، حجم مجمـع اللبن واستخدام وحدة

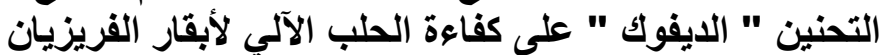

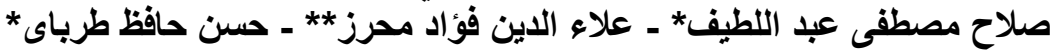

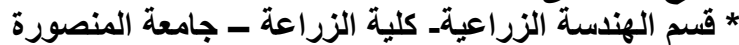
* * معهد بحوث الإتتاج الحيواني- مركز البحوث الزراعية - وزارة الزراعة الزية

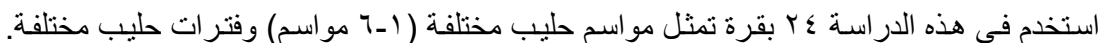

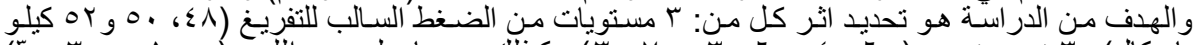

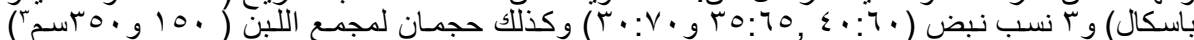

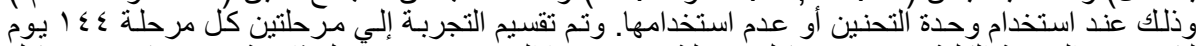

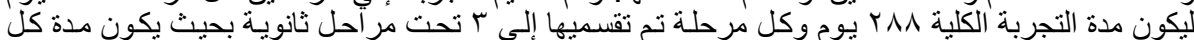

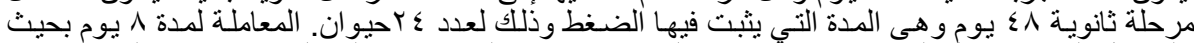

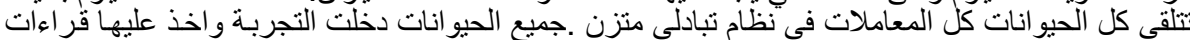

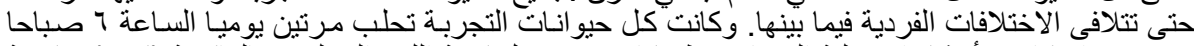

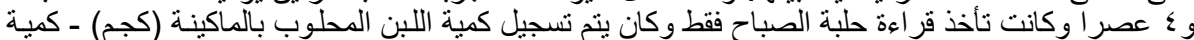

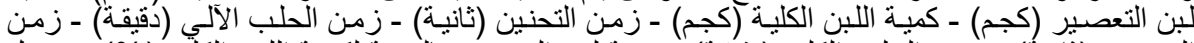

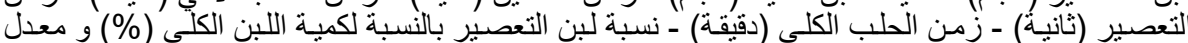

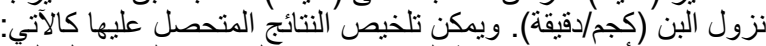

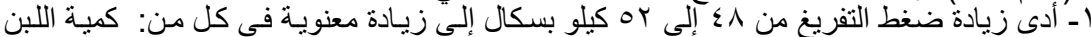

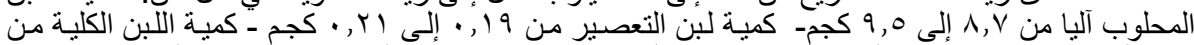

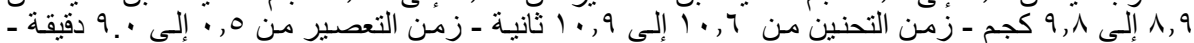

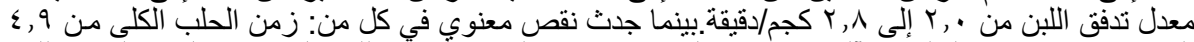

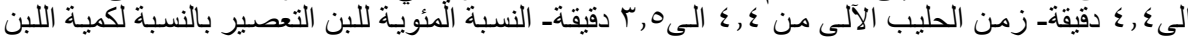

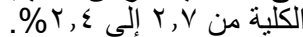

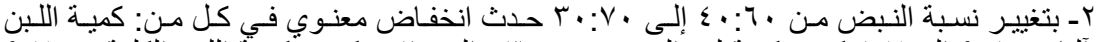

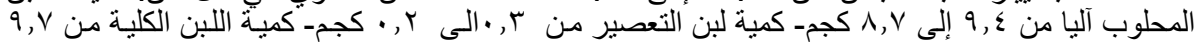

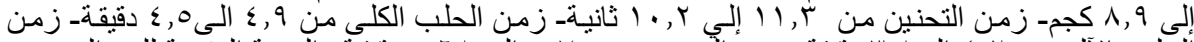

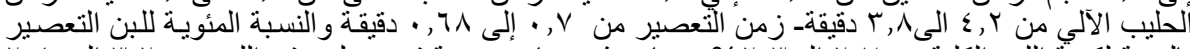

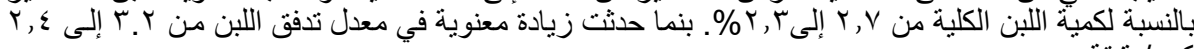

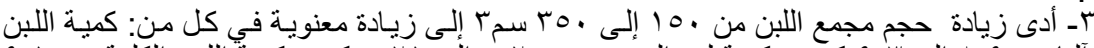
كجم/ذقيقة.

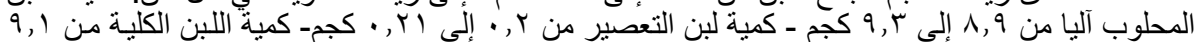

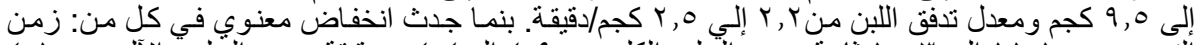

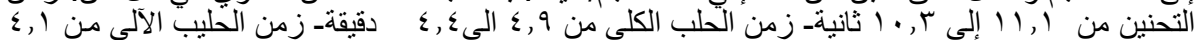

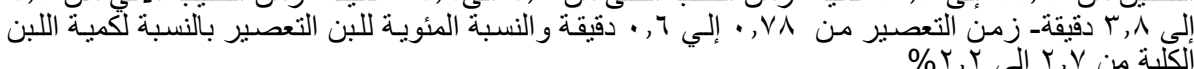

ع ـأدى استخدام وحدة التحنين " الديفوك " إلي زيادة معنوية في كل من: كمية اللبن المحلوب آليا من

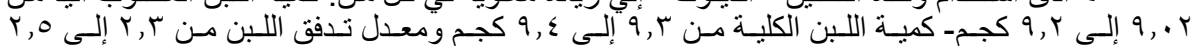

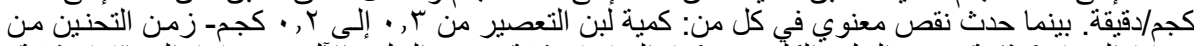

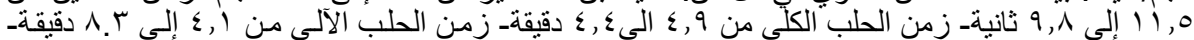

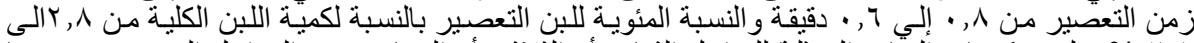

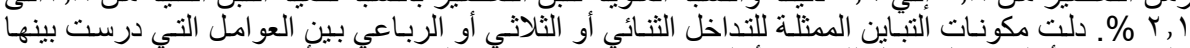

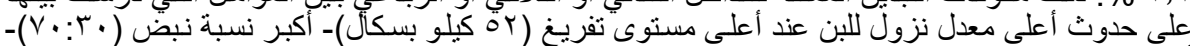

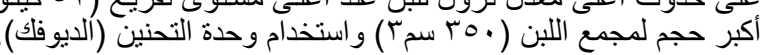

